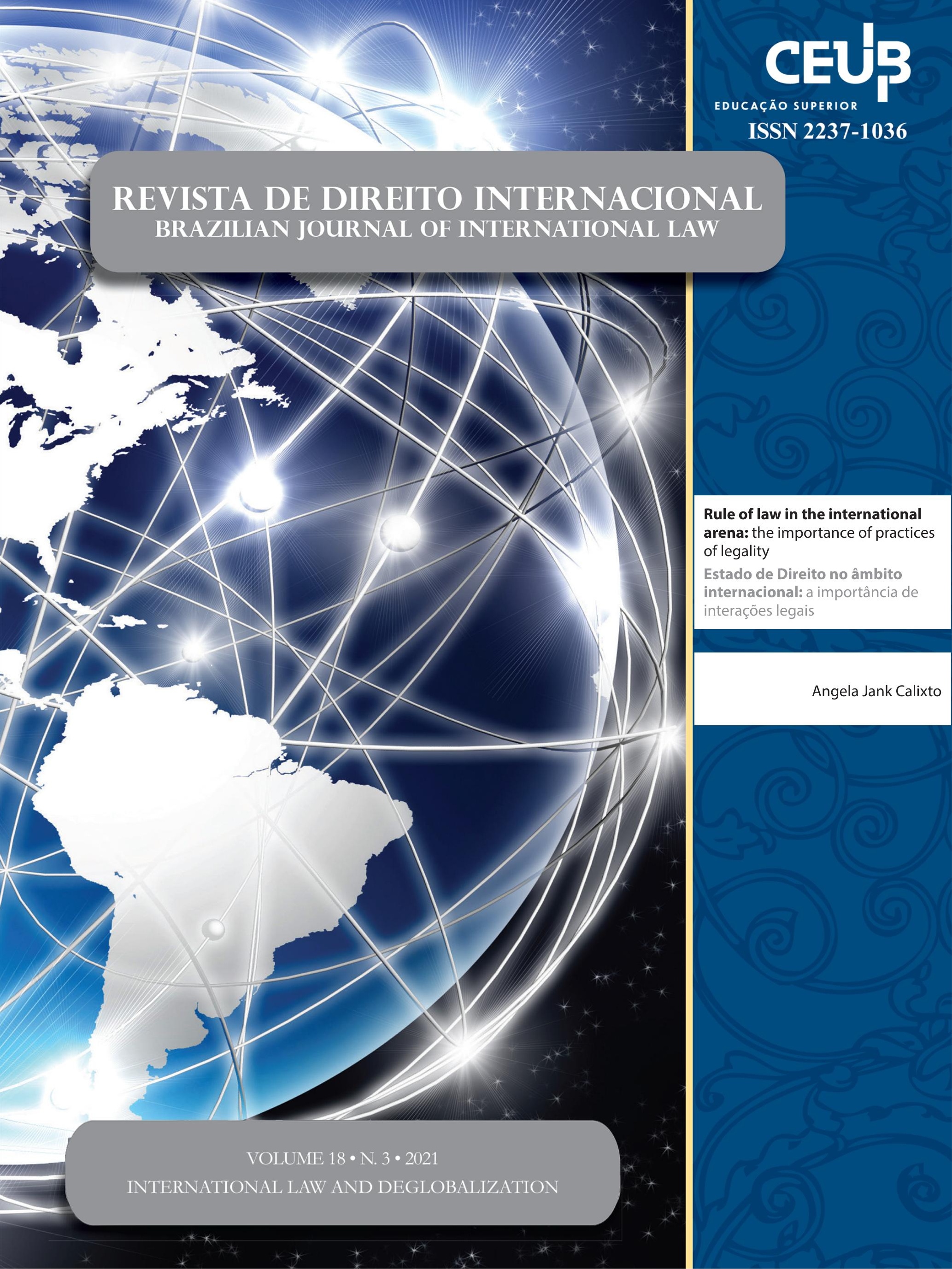




\section{Sumário}

Dossiê

EDITORIAL: INTERNATIONAL LAW AND DE-GLOBALIZATION 16 Ivette Esis, Jaime Tijmes e Juan Enrique Serrano

El régimen jurídico de la Inversión Extranjera Directa: ¿De la limitación a la desGLOBALIZACIÓN?

Ivette Esis Villarroel e Yoselyn Bermúdez Abreu

Desglobalização, Brexit e os novos acordos entre Reino Unido e União Europeia .34 Angela Limongi Alvarenga Alves e Daniel Freire e Almeida

FisCALIDAD Y DESGLOBALIZACIÓN EN UN MUNDO CRECIENTEMENTE UNILATERAL Julio César Muñiz Pérez

Covid, Covax e o Refluxo da Governança Global Salem Hikmat Nasser e Luiza Nogueira Papy

The International Monetary Fund and COVID-19: Old and New Challenges of a Post-World War II INTERNATIONAL INSTITUTION

Virdzhiniya Petrova Georgieva

Artigos Sobre outros temas

RULE OF LAW IN THE INTERNATIONAL ARENA: THE IMPORTANCE OF PRACTICES OF LEGALITY . 112 Angela Jank Calixto

THE WITHDRAWAL OF MEMBER-STATES FROM HUMAN RIGHTS COURTS: IS THE JUDICIALIZATION OF MEGA-POLITICS A NECESSARY CONDITION?. 132

Mikelli Marzzini Lucas Alves Ribeiro e Ernani Rodrigues de Carvalho Neto 
Princípio da precaução e mudança climática: uma análise do Acordo de Paris e das Conferências das Partes.

Jamille Bergamaschine Mata Diz e Carolina Mendonça de Siqueira

A INTERAÇÃo ENTRE OS ESPAÇOS CONSTITUCIONAIS NACIONAIS E INTERNACIONAIS E SEUS IMPACTOS NO SISTEMA DE FONTES DO DIREITO: AS LIÇÕES DA PROTEÇÃO COOPERATIVA DE DIREITOS HUMANOS E O CASO DA INTEGRAÇÃO EUROPEIA ...................................................... 173

Diego Fernandes Guimarães

WTO’s Engagement with National Law: Three Illustrations from India 193 Ravindra Pratap

GESTÃo MIGRATÓRIA E INTEGRAÇÃo REGIONAL: UMA ANÁLISE SOBRE A REGULAMENTAÇÃo NORmativa dos fluxos migratórios irregulares na União Europeia À luz do Novo Pacto Europeu sobre Migração e Asilo.................................................................. 212 João Mauricio Malta Cavalcante Filho e Eugênia Cristina Nilsen Ribeiro Barza

The African Regional Human and Peoples' Rights System: 40 years of progress and CHALLENGES. 232 Juan Bautista Cartes Rodríguez

The USMCA Sunset Clause 258 Jaime Tijmes-Ihl e Yvonne Georgina Tovar Silva

REFLEXÕES SOBRE A UNIVERSALIDADE DO DIREITO INTERNACIONAL DOS DIREITOS HUMANOS A RESPEITO DA PROTEÇÃO ÀS MULHERES 273 Érica Rios de Carvalho

A CRItical legal anAlysis OF GENDER EQUALITY IN INTERNATIONAL TRADE AgREEMENTS...287 Parul Shukla e Sheikh Sultan Aadil Huque

FEMinicídio, FEMicídio E Ódio NA AGENDA: o ASSASSinAto DAS MUlHERES NA AmÉriCA LATINA...... 309 Vinícius Ferreira Baptista

LEGAL IDEOLOGY IN THE CONTEXT OF DEVELOPMENT OF THE LEGAL STATE AND FORMATION OF THE CIVIL SOCIETY IN UKRAINE 
Direito INTERNACIONAL PÚBLICO NO ENTREgUERRAS (1919-39): A INSTITUCIONALIZAÇÃO DOS PROJETOS JURÍDICOS DE PAZ E MANEJO DOS POVOS NÃO SOBERANOS.

Hugo Luís Pena Ferreira

O Caso Gomes Lund (“Guerrilha Do Araguaia”) dez anos depois: Desafios para o cumPRIMENTO INTEGRAL PELO ESTADO BRASILEIRO

João Gabriel Archegas, Felipe Klein Gussoli e Vivian Cristina Lima López Valle

DiÁlogos museológicos: o Regime jurídico brasileiro e o Código de Ética do ConseLHo InTERnacional de Museus.

Paula Gonçalves do Carmo, Emerson Gabardo e Daniel Wunder Hachem 


\title{
Rule of law in the international arena: the importance of practices of legality*
}

\section{Estado de Direito no âmbito internacional: a importância de interações legais}

Angela Jank Calixto**

\begin{abstract}
Despite the assertion of the need to promote the Rule of Law in the international sphere, there is still a great terminological imprecision regarding the concept. Such imprecision generates criticism regarding the use of the term in international relations, raises doubts about the possibility of adopting an international concept of Rule of Law and makes it difficult to delineate the measures to be taken for its promotion. In this original research, conducted by the deductive method and characterized as being theoretical, qualitative, descriptive, bibliographic and documental, it is sought to debate the existing problems for the acceptance of a basic concept of the term Rule of Law in the international sphere, as well as to identify in what sense the Rule of Law should be understood, what are its inherent elements and how it can be achieved and promoted in such sphere. The hypothesis articulated is that even though domestic concepts of the Rule of Law cannot be transposed to the international sphere, enough elements can be found in such sphere to support the adoption of an international conception of the term. Adopting a theoretical constructivist approach, it is concluded that the promotion of the Rule of Law in the international sphere depends on the construction of a social environment in which the obligation/authority of international law is recognized, a construction that is carried out by constant practices of legality.
\end{abstract}

Keywords: Rule of Law; Obligation; International Law; Practices of legality.

\section{Resumo}

Apesar da afirmação da necessidade de promoção do Estado de Direito na esfera internacional, ainda hoje há grande imprecisão terminológica quanto ao conceito. Tal imprecisão gera críticas relativas à utilização do termo nas relações internacionais, levanta dúvidas quanto à possibilidade de adoção de uma concepção internacional de Estado de Direito e torna difícil a delimitação das medidas a serem tomadas para tal promoção. Procura-se por meio dessa pesquisa original, conduzida pelo método dedutivo e caracterizada por ser teórica, qualitativa, descritiva, exploratória, bibliográfica e documental, debater as problemáticas existentes para a aceitação de um conceito base quanto ao termo na esfera internacional, bem como identificar em que sen- 
tido deve o Estado de Direito ser compreendido, quais seus elementos inerentes e como pode ele ser logrado e promovido e tal esfera. A hipótese articulada é a de que embora conceitos domésticos de Estado de Direito não possam ser transpostos para a esfera internacional, podem ser encontrados nessa esfera elementos suficientes para apoiar a adoção de uma concepção internacional do termo. Adotando-se uma abordagem teórica de cunho construtivista, conclui-se que a promoção do Estado de Direito na esfera internacional é dependente da edificação de um ambiente social em que se reconhece a obrigatoriedade/autoridade do direito internacional, a qual é levada a efeito a partir de constantes práticas de legalidade.

Palavras-chave: Estado de Direito; Obrigatoriedade; Direito internacional; Práticas de legalidade.

\section{Introduction}

In the international sphere, the need of taking measures to promote the Rule of Law, whether domestically or internationally, is continually and incisively advocated as a pressing measure for the proper functioning of international relations and for advancing in the pursuit of the international community's main objectives.

First mentioned in an international treaty in 1993, at the Vienna Convention, and referred to by the United Nations' Security Council since 1996, the need to promote the Rule of Law has along the years been referenced as an important United Nations (UN) political strategy in a series of documents and declarations. Reference to the concept is identified, for example, in the UN annual resolutions entitled Streghthening of the Rule of Law, in the Millennium Declaration (2000), in the report The Rule of Law and transitional justice in conflict and post-conflict societies (2004), in the 2005 World Summit Outcome, in the final document of Rio+20 (The Future we Want), in the 2012 Declaration of the High-Level Meeting of the General Assembly on the Rule of Law at the national and international levels and in the UN 2030 Agenda, in addition to being referred to in important human rights protection instruments, such as the Universal Declaration, the European Convention, the American Declaration and the African Charter.

Recognized as applicable to international relations, the concept is today seen as a core value of the United
Nations and as a significant political ideal of governmental legitimacy, being repeatedly identified as an essential means for the protection of human rights, for democracy and for sustainable development. The international community identifies that the promotion of the Rule of Law is urgently needed, considering that by allowing the channeling of power through law it creates conditions for overcoming the main problems that impact countries around the globe.

However, despite the international community's recognition of the indispensability of promoting the Rule of Law, the possibility of referring to the concept in the international arena still raises debates, given the lack of agreement on the elements that are inherent to the concept. The conceptual imprecision generates a series of criticisms regarding the use of the term in international relations, raises doubts about the possibility of adopting an international concept of the Rule of Law and makes it difficult to delineate the measures to be taken for its promotion.

In view of the difficulties that permeate the subject, the conduction of a study that considers the factors that create conditions for such promotion, especially in the international sphere, is needed, precisely in view of the essentiality of the Rule of Law to advance in the protection of human rights and in the promotion of development in its three spheres (namely, economic, social and environmental), issues considered to be of central focus by the international community. Thus, the aim of this work is to debate the existing problems for the acceptance of a basic concept of the term in the international sphere, as well as to identify in what sense the Rule of Law should be understood, what are its inherent elements and how it can be achieved and promoted in such sphere.

The hypothesis articulated is that even though domestic concepts of the Rule of Law cannot be transposed to the international sphere, enough elements can be found in such sphere to support the adoption of an international conception of the term. For this analysis, the paper is divided into two topics. In the first, the difficulties in defining Rule of Law will be analyzed, in order to understand the reasons behind the lack of a precise definition of the term in the international sphere. In the second, considerations will be made about the elements that make up the concept in the international 
sphere, in order to outline which measures are necessary to promote the concept.

The research, conducted by the deductive method, is eminently theoretical and qualitative, having, with regard to its objectives and means, a descriptive, exploratory, bibliographical and documental nature. A constructivist approach to international relations (as opposed to rationalist descriptions of international relations), based mainly on the theoretical approaches of Brunnée and Toope ${ }^{1}$ and Gorobets ${ }^{2}$, is adopted, importance being given to the social environment and constant interactions as main mechanisms that influence international law and politics.

\section{The difficulties of a direct transposition of the concept to the international level}

Although no government in the world (including countries considered authoritarian and illiberal regimes) rejects the Rule of Law, it being evident that adherence to its terms is accepted as a measure of governmental legitimacy, an international conception of the Rule of Law is still an elusive notion today, its meaning being difficult to precisely articulate. As asserted by Tamanaha, "the Rule of Law is in the peculiar state of being the preeminent political ideal of legitimacy in the world today, without a precise agreement on what precisely it means"

Given the inclusion of the term as a relevant aspect for the good functioning of international relations, it is necessary to make some clarifications as to what can be understood as Rule of Law and as to the applicability of the term in the international sphere. This is because the lack of establishment of official criteria to characterize the term (there is no undisputed official concept of

\footnotetext{
BRUNNÉE, Jutta; TOOPE, Stephen. Interactional legal theory, the international Rule of Law and global constitutionalism. In: LANG, A.; WIENER, A. (ed.). Handbook on global constitutionalism. Cheltenham: Edward Elgar Publishing, 2017. p. 170-182; BRUNNÉE, Jutta; TOOPE, Stephen. Legitimacy and legality in international law: an interactional account. Cambridge: Cambridge University Press, 2010.

2 GOROBETS, Kostiantyn. The international Rule of Law and the idea of normative authority. Hague Journal on the Rule of Law, v. 12, p. 227-249, 2020.

3 TAMANAHA, Brian Z. On the Rule of Law: history, politics, theory. Cambridge: Cambridge University Press, 2004. p. 04.
}

the term in the international scenario) prevents its promotion, a fact that can hinder the adequate protection of human rights and the promotion of democracy and sustainable development.

Some reference to the elements that characterize the Rule of Law can be found in Aristotle; Roman jurists; Enlightenment philosophers like Hobbes, Locke, Rousseau, Montesquieu; and German philosophers such as Kant and Hegel in the 19th century and Hayek, Rawls, Scalia and Zemin in the 20th century, each author bringing a different contribution to the comprehension of the concept.

The literature in general uses the term Rule of Law to eminently refer to the relationship between law and the exercise of power, but, despite this fact, there is no single and widely accepted definition of the concept, disagreements stemming from differences between countries' distinct legal, political and cultural histories and the fact that there is no consensus concerning the elements that are inherent to the concept even among those countries with similar historical traditions ${ }^{4}$.

Regarding the disagreements between the different legal traditions, these discussions derive from the fact that there is no exact correlation between the use of the term in countries with common law traditions and civil law traditions, of European influence. In the common law tradition, the term Rule of Law presupposes the existence of an autonomous law independent of the State figure (which is not included in the concept), while in civil law traditions the Rechtsstaat, the État de Droit or the Statto di Diritto dictate that it is up to the State to limit itself through the creation of laws, the concept being eminently linked to the figure of the State .

It is important to note that the association of the Law with the figure of the State (association that occurs in civil law countries) derives from the fact that Law and the State are traditionally seen as complimentary and even synonyms. In this view, the Law is normally seen as an institutional order established by a sovereign authority, a State, which maintains such order through

\footnotetext{
${ }^{4}$ KRYGIER, Martin. Rule of Law (and Rechtsstaat). In: SILKENAT, James R.; HICKEY JR., James E.; BARANBOIM, Peter D. (ed.) The Legal Doctrines of the Rule of Law and the Legal State (Rechtsstaat). Switzerland: Springer, 2014. p. 45-60.

${ }^{5}$ KRYGIER, Martin. Rule of Law (and Rechtsstaat). In: SILKENAT, James R.; HICKEY JR., James E.; BARANBOIM, Peter D. (ed.) The Legal Doctrines of the Rule of Law and the Legal State (Rechtsstaat). Switzerland: Springer, 2014. p. 45-60.
} 
the threat of the exercise of coercive power. This correlation creates certain skepticism as to the possibility of an existence of an international conception of the Rule of Law and must be overcome ${ }^{6}$.

Despite the different historical roots and particular legal traditions, Kirchheimer teaches that there is a common denominator between the concepts, which lies in the simple idea that individuals are better protected when there are specific demands that can be addressed to institutions limited by norms and criteria of permanence and legal security, than when entrusted to transitory personal relationships and situations, characterized by imprecision ${ }^{7}$. Considering this, scholars in general may present different views of the Rule of Law, but no one denies that the concept refers to the realization of impartial justice, free from oppression or arbitrary power ${ }^{8}$.

Thus, in all traditions, Rule of Law refers to the limitation of the indiscriminate use of power and its constraint through the law ${ }^{9}$, Palombella teaching that in any and all definitions the Rule of Law concerns the existence of norms that limit or counterbalance power, regardless of their form, structure or who applies them, it being a concept applied to confront any form of power and government and the arbitrariness resulting from the misuse of power ${ }^{10}$.

This search for limiting power and arbitrariness through law is the main element of the concept at the national level, whether in the Anglo-Saxon tradition or in the continental European tradition or in other con-

\footnotetext{
${ }^{6}$ BARBOSA, Luiza Nogueira; MOSCHEN, Valesca Raizer Borges. O direito transnacional ("global law") e a crise de paradigma do estado-centrismo: é possível conceber uma ordem jurídica transnacional? Revista de Direito Internacional, Brasília, v. 13, n. 3, p. 145-158, 2016. 7 KIRCHHEIMER, Otto. The Rechtsstaat as Magic Wall. In: SCHEUERMAN, William E. (Ed.) The Rule of Law under siege: selected essays of Franz L. Neumann and Otto Kirchheimer. California: University of California Press, 1996. p. 243-263.

8 SELLERS, Mortimor N. S. What is the Rule of Law and why is it so important? In: SILKENAT, James R.; HICKEY JR., James E.; BARANBOIM, Peter D. (ed.). The legal doctrines of the Rule of Law and the Legal State (Rechtsstaat). Switzerland: Springer, 2014. p. 3-14.

9 SANTOS, Gilberto Antônio Duarte. O conceito de Rule of Law nas relações internacionais: direitos humanos e restrições à liberdade de navegação nos oceanos. 2015. Dissertação (Mestrado em Relações Internacionais) - Instituto de Relações Internacionais, Universidade de Brasília, Brasília, 2015.

10 PALOMBELLA, Gianluigi. The Rule of Law as an institutional ideal. In: MORLINO, Leonardo; PALOMBELLA, Gianluigi (ed.). Rule of Law and democracy: inquiries into internal and external issues. Leiden: Brill, 2010. p. 3-37.
}

texts, such as in the Arab world, where the idea of sovereignty of law in opposition to unrestricted power is also established as an essential element ${ }^{11}{ }^{12}$. Since its origin (in the Magna Carta of 1212 and the Bill of Rights, for instance), the term has been associated with the search for the prevention of tyranny, which is why in its various meanings it is identified with the requirement of legal processes and norms that enable accountability and the consequent constriction of the abuse of power ${ }^{13}$.

Furthermore, and of greater significance than the conceptual imprecision resulting from the evolution of the concept in countries of different legal traditions, there are discussions regarding the elements that are inherent to the concept, or rather, regarding the adoption of a "formal" or "minimalist" perspective of the Rule of Law, or of a "substantial" or "material" perspective of the term. The minimalist perspective limits the analysis to the formal properties of Law and legal institutions, identifying such properties as the only elements necessary to define the concept, while the material perspective is broader, requiring the analysis of the existence of substantive elements in the Law, such as democracy, economic freedom and respect for human rights ${ }^{14}$.

The minimal or formal approach brings together a smaller number of components, emphasizing the instrumental limits to the exercise of State authority ${ }^{15}$, pointing out as requirements of the Rule of Law only the existence of a positive right and its fulfillment and removing from the concept any moral connotation or weight ${ }^{16}$. It is based on the idea of the importance of

11 CHESTERMAN, Simon. An International Rule of Law? American Journal of Comparative Law, v. 56, n. 2, p. 1-39, 2008.

12 In this sense Peerenboom argues that the rule of law is a concept accepted by different ideological perspectives, whether among Christians, Buddhists, libertarians, community, Muslims, democrats, socialists and neo-Marxists, among others, all finding significant value in the concept. In: PEERENBOOM, Randall. Human Rights and Rule of Law: what's the relationship? Georgetown International Law Review, v. 36, p. 809-945, 2005.

13 ETHERTON, Terence. The universality of the Rule of Law as an international standard. Israel Law Review, v. 53, n. 3, p. 469-483, 2018.

${ }^{14}$ KRYGIER, Martin. Rule of Law (and Rechtsstaat). In: SILKENAT, James R.; HICKEY JR., James E.; BARANBOIM, Peter D. (ed.) The Legal Doctrines of the Rule of Law and the Legal State (Rechtsstaat). Switzerland: Springer, 2014. p. 45-60.

15 CHESTERMAN, Simon. An International Rule of Law? American Journal of Comparative Law, v. 56, n. 2, p. 1-39, 2008.

16 SANTOS, Gilberto Antônio Duarte. O conceito de Rule of Law nas 
formality for the effectiveness of legal orders and, specifically in the international order, due to the fact that such formality "makes it possible for each State to understand its substantive conception of global society, as well as its vision of the scope of sovereign freedom in legal concepts and categories"17_ ${ }^{18}$.

Academics such as Dicey, Friedrich Hayek and Josepf Raz defend the formal conception, basing their definition of the Rule of Law on the eight principles of the "morality of law" of Lon Fuller ${ }^{19}$, and asserting that issues such as substantive values can exist in the law, but they are not strictly related to the Rule of Law. For the theorists, for the concept in evidence it only matters that there are rules and mechanisms that prevent the State from manipulating citizens.

Dicey formulated the first modern analysis of the Rule of Law in a liberal democratic system, and his concept of the Rule of Law, in its formal perspective, is widely accepted, despite being criticized. For him, the Rule of Law has three meanings, namely, the absolute supremacy or predominance of law in opposition to the arbitrary influence of power; equality before the law or the equal subjection of all classes and even the rulers to the law; and the subjection to a general jurisdiction of ordinary courts, which are the best source of legal protection $^{20}$.

In Hayek's conception, also a liberalist, the Rule of Law must be understood as a pressing measure for freedom. For the scholar, the term means that the gover-

relações internacionais: direitos humanos e restrições à liberdade de navegação nos oceanos. 2015. Dissertação (Mestrado em Relações Internacionais) - Instituto de Relações Internacionais, Universidade de Brasília, Brasília, 2015.

17 KOSKENNIEMI, Martti. Entre a apologia e a utopia: A política do direito internacional. Revista de Direito Internacional, Brasília, v. 15, n. 1, p. $25,2018$.

${ }^{18}$ In the original: “[...] torna possível a cada Estado compreender sua concepção substancial de sociedade global, bem como sua visão acerca do alcance da liberdade soberana em conceitos e categorias jurídicas".

19 Lon Fuller argues that the rule of law is a necessary internal virtue of any functioning legal system, without which law does not exist. For him, eight conditions must be met so that it is possible to speak of the Rule of Law, namely: (1) a system of general rules; (2) publication of the rules; (3) no retroactive application; (4) clear and intelligible rules; (5) non-existence of contradictory rules; (6) practicable rules; (7) consistency of rules over time and (8) congruence between official actions and stated rules. In: FULLER, Lon. The morality of law. New Haven: Yale University Press, 1969.

${ }^{20}$ DICEY, Albert Venn. Introduction to the Study of the Law of the Constitution. London: Macmillan and Co, 1915. nment, in all its actions, is governed by rules set and announced in advance - rules that allow to predict with reasonable certainty how the authority will use its coercive powers in certain circumstances and to plan individual businesses based on that knowledge. For him, an order governed by the Rule of Law has three attributes: laws must be general, equally applicable and endowed with certainty ${ }^{21}$. Hayek's definition refers to the notion of "legal freedom", in the sense that the Rule of Law promotes freedom by allowing individuals to know the extent of activities they can exercise freely, without being exposed to government coercion ${ }^{22}$.

Another important theorist, allied to the formal conception of the Rule of Law, is Joseph Raz. For the theorist, the Rule of Law is not to be confused with legal norms or with the purposes of a State, being, in fact, a negative virtue, associated with the capacity that norms have to guide the conduct of individuals, in order to prevent arbitrary use of Law by public agents. In his view, the Rule of Law is indifferent to values, not being a summary of the general qualities that a legal system should aspire, not being synonymous with general justice and not referring to democratic values, but only referring to the existence of factors that allow the law to provide effective guidance to those it addresses ${ }^{23}$.

In this regard, he lists 08 elements that must be found in a system based on the Rule of Law: (1) all laws must be prospective, open and clear; (2) the law must be relatively stable; (3) the elaboration of specific laws (specific legal orders) must be guided by open, stable, clear and general rules; (4) the independence of the judiciary must be guaranteed; (5) the principles of natural justice must be observed; (6) Courts should have review powers over the implementation of the other principles; (7) Courts should be easily accessible; and (8) crime prevention agencies must not be allowed to pervert the $\operatorname{law}^{24}$.

In these "thin" conceptions, it is argued that the Rule of Law is just one of the virtues of a legal system, while there are others, such as justice, for example, that a sys-

${ }^{21}$ HAYEK, Friedrich August von. Law, Legislation and Liberty: rules and order. Chicago: University of Chicago Press, 1978.

22 TAMANAHA, Brian Z. On the Rule of Law: history, politics, theory. Cambridge: Cambridge University Press, 2004.

${ }_{23}$ RAZ, Joseph. The authority of law: essays on law and morality. 2. ed. Oxford: Oxford University Press, 2009.

${ }^{24}$ RAZ, Joseph. The authority of law: essays on law and morality. 2. ed. Oxford: Oxford University Press, 2009. 
tem may or may not possess to a certain degree. Rule of Law, therefore, relates to the idea of legal formality, as a set of requirements about how the law should work.

Saying that there is the Rule of Law in a system means that there are clear rules, known in advance, stable, that do not prescribe the impossible, that are not applied retroactively, that are created through clear and known processes, according to pre-fixed rules, which are generically applicable to everyone, without distinction, as well as that the courts are accessible and allow the review of government guidelines. There are no requirements regarding the content of the norms ${ }^{25}$. There are no considerations about fundamental rights, equity or justice, only procedural requirements and restrictions on the form of the law being imposed ${ }^{26}$.

From this perspective, the Rule of Law is more easily identifiable, because it has fewer elements. For this reason, it is the view that is most widely accepted by different governments, particularly non-democratic societies, which tend not to identify the term with issues that refer to the analysis of the morality of $\mathrm{Law}^{27}$. This is because non-democratic governments identify the material perspective with a kind of imperialism of values and institutions, which leads to ethical disputes, and defend that the broadening of the term in such a way to include any connotation that is desirable removes the usefulness of using the concept ${ }^{28}$. As pointed out by Krygier:

\footnotetext{
Partisans of thin versions, on the other hand, often associate the thickness insisted on by moralists with a combination of parochialism and imperialism about values and institutions. Why should we assume, either as a matter of fact or of value, that all cultures value the same things from law? Meta-ethical disputes this raises are too large to be resolved here, but there is another worry about too thick an account of the Rule of Law. As Joseph Raz has argued, 'thick' conceptions have a tendency to wash away all distinction between the Rule of Law and anything else we might want ${ }^{29}$.
}

\footnotetext{
25 GOROBETS, Kostiantyn. The international Rule of Law and the idea of normative authority. Hague Journal on the Rule of Law, v. 12, p. 227-249, 2020.

26 TAMANAHA, Brian Z. On the Rule of Law: history, politics, theory. Cambridge: Cambridge University Press, 2004.

${ }^{27}$ BINGHAM, Tom. The Rule of Law. Londres: Penguin Books, 2010.

${ }^{28}$ KRYGIER, Martin. Rule of Law (and Rechtsstaat). In: SILKENAT, James R.; HICKEY JR., James E.; BARANBOIM, Peter D. (ed.) The Legal Doctrines of the Rule of Law and the Legal State (Rechtsstaat). Switzerland: Springer, 2014. p. 45-60.

${ }^{29}$ KRYGIER, Martin. Rule of Law (and Rechtsstaat). In: SILK-
}

It is often preferable to use such "thin" approaches to make comparisons between countries, as it allows the concept to be applied to heterogeneous contexts and to non-democratic states ${ }^{30}$. It refers to a way of conceiving the term coherently with the various contexts in which it is invoked, a coherence that although requires the non-inclusion of political values, such as democracy and the promotion of human rights, in its definition, provides the means for the realization of these political values. In the words of Chesterman:

To conceive of the Rule of Law in a manner cohe-
rent across the many contexts in which it is invoked
requires a formal, minimalist understanding that
does not seek to include substantive political out-
comes - democracy, promoting certain human ri-
ghts, redistributive justice or laissez-faire capitalism,
and so on - in its definition. These outcomes are
more properly sought in the political realm. 7 Ne-
vertheless, examination of the functional manner in
which the Rule of Law is deployed in international
forums suggests important qualifications on how
the Rule of Law may be adapted as a meaningful
concept at the international level. In other words,
agreement on the meaning of Rule of Law requires
a formal conception of its content, but how that
content is applied to international law - where the
primary challenge is not the vertical relationship
of subjects to a sovereign, but the horizontal rela-
tionship of subjects to other subjects - requires a
functionalist understanding of its use.

Other authors, however, allied to the substantial perspective, assert the impossibility of associating the term only with legal formality.

Among them, Philip Selznick suggests that the Rule of Law has a more important connotation than just the limitation of abuse of power based on legality, asserting that it holds at its core the analysis of ethical or moral issues ${ }^{32}$. Similarly, the renowned theorist Bobbio clarifies that the Rule of Law in its strong sense is cha-

ENAT, James R.; HICKEY JR., James E.; BARANBOIM, Peter D. (ed.) The Legal Doctrines of the Rule of Law and the Legal State (Rechtsstaat). Switzerland: Springer, 2014. p. 53.

30 SANTOS, Gilberto Antônio Duarte. O conceito de Rule of Law nas relações internacionais: direitos humanos e restrições à liberdade de navegação nos oceanos. 2015. Dissertação (Mestrado em Relações Internacionais) - Instituto de Relações Internacionais, Universidade de Brasília, Brasília, 2015.

31 CHESTERMAN, Simon. An International Rule of Law? American Journal of Comparative Law, v. 56, n. 2, p. 3, 2008.

32 SELZNICK, Philip. Legal cultures and the Rule of Law. In: KRYGIER, Martin; CZARNOTA, Adam. (ed.) The Rule of Law after communism. Aldershot: Ashgate/Dartmouth, 1999. p. 21-38. 
racteristic of liberal doctrine ${ }^{33}{ }^{34}$, demanding that the constitutionalization of natural rights be considered an inherent element of the term. In this view, the Rule of Law would not only refer to the subordination of public powers to norms, but also to the material subordination of norms to some inviolable fundamental rights.

Ronald Dworkin also presents a substantialist perspective, understanding that individual rights necessarily compose the concept of Rule of Law. For the theorist, Law consists of more than norms, it also harbors immanent moral and political principles, which are present even when they are not previously recognized. According to Dworkin, the community has a set of coherent and shared political and moral principles and the set of norms represents the community's effort to capture moral rights. Due to this, material issues necessarily are an inherent part of the Rule of Law, even if moral and political principles are not transposed into positive norms ${ }^{35}$.

It is important to note that among the different substantial conceptions some are "thicker" than others, depending on the values that are instilled in the notion of Rule of Law. According to Tamanaha, in addition to the criteria of legal formality inherent to all conceptions of Rule of Law, the thinner substantial versions list the presence of individual rights in the concept, the intermediate ones insert values such as dignity, democracy or justice ${ }^{36}$, while the thicker versions, in addition

33 BOBBIO, Norberto. Liberalism and Democracy. Translation: Martin Ryle and Kate Soper. London: Verso, 1990.

${ }^{34}$ For Bobbio, the concept in its strong sense is composed of all constitutional mechanisms that prevent or hinder the arbitrary and illegitimate exercise of power and prevent the abuse or illegal exercise of this power, such as: the control of the Executive by the Legislative; the control of the Legislative by a jurisdictional court; a relative autonomy of the local government in relation to the central one; an independent judiciary; and the material submission of laws to fundamental rights. On the other hand, for the theorist, the concept is weak when referring only to the non-despotic State, that is, governed by laws and not by men. In: BOBBIO, Norberto. Liberalism and Democracy. Translation: Martin Ryle and Kate Soper. London: Verso, 1990.

35 DWORKIN, Ronald. A matter of principle. Harvard University Press: Cambridge, 1985.

36 This intermediate version, is the notion primarily adopted by Western societies. For Tamanaha, however, it is forgotten that the basis of the Rule of Law does not include, as an intrinsic requirement, democracy or individual rights, which for the theorist are only instilled in the concept because normally the three elements (legal formality, democracy and individual rights) come and work together in Western liberal democracies. In: TAMANAHA, Brian Z. On the Rule of Law: history, politics, theory. Cambridge: Cambridge Univer- to individual rights and mentioned values, add to the list elements such as equity and social well-being ${ }^{37}$. Anyway, despite the different views, what is perceived is that all substantial theories of the Rule of Law are broader than the formal perspectives, referring to the presence in the concept of set of ideals aimed at promoting values ${ }^{38}$.

In general, in addition to the demand of the existence of norms that have the characteristics clarified by Fuller, substantial perspectives normally convey the necessity of such norms being promulgated by a democratic legislature, of the existence of independent courts, capable of ensuring that such norms are enforced, of the possibility of holding governments accountable, in order to prevent abuse or oppression, and of a focus on the protection and promotion of human rights and dignity $^{39}$.

Gorobets warns that, in this perspective, the Rule of Law appears as an element of a theory of justice, not referring to a virtue of a legal system, but to "The" virtue of the system, the political and moral ideal that encompasses principles and values that form an image of a better society ${ }^{40}$. The concept in this view includes values such as dignity, democracy, equality, justice, freedom, etc. As Dworkin points out, the Rule of Law, in this conception, "[...] is the ideal of rule by an accurate public conception of individual rights. It does not distinguish [...] between the Rule of Law and substantive justice; on the contrary it requires, as part of the ideal of law, that the rules $[\ldots]$ capture and enforce moral rights" ${ }^{41}$.

Although the concept is not fully endorsed by the international community ${ }^{42}$, this is the view adopted by

sity Press, 2004.

37 TAMANAHA, Brian Z. On the Rule of Law: history, politics, theory. Cambridge: Cambridge University Press, 2004.

38 CHESTERMAN, Simon. An International Rule of Law? American Journal of Comparative Law, v. 56, n. 2, p. 1-39, 2008.

39 ETHERTON, Terence. The universality of the Rule of Law as an international standard. Israel Law Review, v. 53, n. 3, p. 469-483, 2018.

${ }^{40}$ GOROBETS, Kostiantyn. The international Rule of Law and the idea of normative authority. Hague Journal on the Rule of Law, v. 12, p. 227-249, 2020.

41 DWORKIN, Ronald. A matter of principle. Harvard University Press: Cambridge, 1985. p.11-12.

42 According to Arajärvi (2018), the lack of full endorsement of the concept is due precisely to the fact that some States do not fully agree with the elements used to clarify the concept, since the express reference to the protection of human rights and the institution of a diversity of elements for its implementation implies the adoption of a concept permeated by moralistic conceptions about good govern- 
the UN, according to the definition of Rule of Law presented in 2004 by the then UN Secretary General, who, based on the Brabimi Report (1993), defined in the report The Rule of Law and transitional justice in conflict and post-conflict societies the concept as:

[...] a principle of governance in which all persons, institutions and entities, public and private, including the State itself, are accountable to laws that are publically promulgated, equally enforced and independently adjudicated, and which are consistent with international human rights norms and standards. It requires, as well, measures to ensure adherence to the principles of supremacy of law, equality before the law, accountability to the law, fairness in the application of the law, separation of powers, participation in decision-making, legal certainty, avoidance of arbitrariness and procedural and legal transparency ${ }^{43}$.

The UN, through this report, introduces the main bases for the substantive delimitation of the Rule of Law, namely, the consistency of norms with international human rights standards. This consistency is seen by the Organization and by substantial theorists, such as Bingham $^{44}$, Etherton ${ }^{45}$ and Krygier ${ }^{46}$, as an inseparable element of the concept, which should guarantee, for the authors, equal application and protection of individual, social, political and economic rights. Likewise, this is generally the view adopted by human rights activists, as the concept provides rhetorical support for particular political agendas ${ }^{47}$.

The substantial perspective, therefore, refers to a concept related to an ideal condition to be pursued, there being a utopian character in such a definition ${ }^{48}$. In

ance. In: ARAJÄRVI, Noora. The Rule of Law in the 2030 Agenda. The Hague Journal on the Rule of Law, Berlin, v. 10, n. 1, p. 187-217, 2018.

43 UNITED NATIONS [UN]. Security Council. Repport n. $\mathrm{S} / 2004 / 616$. The Rule of Law and transitional justice in conflict and postconflict societies: report of the Secretary General. UN Security Council, 2004, paragraph 6.

${ }^{44}$ BINGHAM, Tom. The Rule of Law. Londres: Penguin Books, 2010.

45 ETHERTON, Terence. The universality of the Rule of Law as an international standard. Israel Law Review, v. 53, n. 3, p. 469-483, 2018.

${ }^{46}$ KRYGIER, Martin. Rule of Law (and Rechtsstaat). In: SILKENAT, James R.; HICKEY JR., James E.; BARANBOIM, Peter D. (ed.) The Legal Doctrines of the Rule of Law and the Legal State (Rechtsstaat). Switzerland: Springer, 2014. p. 45-60.

47 PEERENBOOM, Randall. Human Rights and Rule of Law: what's the relationship? Georgetown International Law Review, v. 36, p. 809-945, 2005.

48 PALOMBELLA, Gianluigi. The Rule of Law as an institutional ideal. In: MORLINO, Leonardo; PALOMBELLA, Gianluigi (ed.). this view, the Rule of Law is "an ideal situation in which international law generates predictability and order, restriction on arbitrary power and equality between actors in the international system respecting human rights" ${ }^{\prime 4}{ }_{-5}$ (free translation).

There are criticisms to this perspective, derived in particular from the defense of the idea that the inclusion of substantial values in the concept may imply the defense of a specific social philosophy, which disregards the different ways of conceiving the law ${ }^{51}$.

The criticisms of Koskenniemi stand out, as he suggests that the substantial conception and its application to the international scene implies in a certain way a type of Western culture domination over other cultures ${ }^{52}$. Similarly, Raz asserts that the association of the Rule of Law with substantial values or with the rule of good law in reality is an attempt to diffuse a complete social philosophy, which, in his view, removes the usefulness of the concept. Considering this, the author concludes that in reality the Rule of Law, that "[...] is just one of the virtues by which a legal system may be judged and by which it is to be judged", should be seen as "[...] a political ideal which a legal system may lack or possess to a greater or lesser degree" 53 .

Although there are claims within the United Nations that it is necessary to give a substantial concept to the Rule of Law, to date no agreement has been reached, due to objections arising from some States. There is only an agreement on the basic elements already pre-agreed upon by the States regarding the concept of the Rule of Law, namely, the authority of law, equality before the law, accountability and non-discrimination

Rule of Law and democracy: inquiries into internal and external issues. Leiden: Brill, 2010. p. 3-37.

49 SANTOS, Gilberto Antônio Duarte. O conceito de Rule of Law nas relações internacionais: direitos humanos e restrições à liberdade de navegação nos oceanos. 2015. Dissertação (Mestrado em Relações Internacionais) - Instituto de Relações Internacionais, Universidade de Brasília, Brasília, 2015.

50 In the original: "[...] uma situação ideal em que o direito internacional gera previsibilidade e ordem, restrição ao poder arbitrário e isonomia entre os atores no sistema internacional respeitando os direitos humanos".

51 RAZ, Joseph. The authority of law: essays on law and morality. 2. ed. Oxford: Oxford University Press, 2009.

${ }^{52}$ KOSKENNIEMI, Martti. From apology to utopia: the structure of international legal argument. Cambridge: Cambridge University Press, 2005.

53 RAZ, Joseph. The Rule of Law and its Virtue. In: RAZ, Joseph. The authority of Law: essays on Law and morality. Oxford: Clarendon Press, 1979. p. 211. 
(as provided for in the 2012 Declaration of the High-Level Meeting of the General Assembly on the Rule of Law at the national and international levels), there being, on the other hand, no consensus on the inclusion of human rights in the concept.

Given this and the criticisms to the substantial conceptions, many researchers, such as Chesterman $^{54}$, praise that a definition that is applicable and acceptable between political and cultural systems is necessarily a formal one, which list as essential elements to the concept only the existence of a government of laws ${ }^{55}$ (which have the basic characteristics suggested by Fuller), the supremacy of law (which relates to the requirement that laws are also applied to state authorities and to state bodies such as the judiciary, which must be independent and transparent for the application of such laws in specific cases) and equality before the law (ie, equal protection without discrimination).

The political neutrality of formal notions makes them more acceptable in the international community ${ }^{56}$, avoiding debates about the superiority of political theories of justice, particular conceptions of economy, political orders and human rights. It avoids accusations of ethnocentrism and imperialism, which, as stated by Peerenboom, is necessary in the current scenario of pluralism and fragmentation of law, culture and society ${ }^{57}$.

Although it is understood that it is not possible to simply transfer a definition built in the domestic level to the international sphere, there being no way of trying to frame all the elements of a particular conception of the Rule of Law to the external plane (as will be discussed below), it is conveyed that in the event of such a transposition, only a formal perspective would have the power to be accepted by the international community.

\footnotetext{
${ }^{4}$ CHESTERMAN, Simon. An International Rule of Law? American Journal of Comparative Law, v. 56, n. 2, p. 1-39, 2008.

55 Chesterman expresses that the government of laws at the international level requires non-arbitrary exercise of power, a fact that is achieved both through the foundational concept of pacta sunt servanda and through the establishment of an international protection of human rights, of regimes for the regulation of international trade and of institutions that guarantee international security. In: CHESTERMAN, Simon. An International Rule of Law? American Journal of Comparative Law, v. 56, n. 2, p. 1-39, 2008.

56 BEAULAC, Stéphane. The Rule of Law in International Law today. In: PALOMBELLA, Gianluigi; WALKER, Neil. (ed.). Relocating the Rule of Law. Oxford: Hart Publishing, 2007. p. 197-223.

57 PEERENBOOM, Randall. Human Rights and Rule of Law: what's the relationship? Georgetown International Law Review, v. 36, p. 809-945, 2005.
}

Thus, in reference to the Rule of Law in the international sphere, it would be necessary to understand the term according to the definition of Dicey, which is widely accepted, that is, in the case of the existence of norms that have the characteristics pointed out by Fuller, which are recognized as supreme and applied equally to all States (aspect strictly related to the limitation of the abuse of power), and in the case of the existence of legal protection through judicial courts.

Now, despite being praiseworthy objectives, the inclusion of elements such as democracy and human rights in the basic concept of the Rule of Law would hinder the possibility of its use in the international sphere. Although human rights permeate international treaties, and there are no norms contrary to human rights in the international sphere, this objective does not integrate the concept of the Rule of Law, and does not constitute a requirement for the affirmation of a Rule of Law at the international level. Furthermore, the demand for democracy is also an issue that is criticized, considering the wide range of States that do not adopt strictly democratic government regimes and that, nevertheless, are part of the international community.

In any case, what has to be understood is that the description of the Rule of Law with the use of one concept or another (whether using formal or substantial perspectives) actually results from the contemplation of the term as a political doctrine and a way to legally protect citizens against abuses of the government. It refers to the existence of a government of laws, in which the supremacy of the law is a necessary issue, in the sense of limiting not only the conduct of subjects of rights, but also of authorities and rulers responsible for its creation and application. Gorobets ponders that the only difference is that 'thin' versions do so " $[. .$. through establishing safeguards as to how laws should be given a proper functionality, and the 'thick' theories through ensuring that laws substantively reflect the values and principles underlying individual rights" ${ }^{\prime \prime 5}$.

As Tamanaha argues, despite the elusive concept, there are three common themes surrounding the Rule of Law, namely, the limitation of the power of the sovereign government by law; the existence of formal legality; and the supremacy of the law, by advocating a

\footnotetext{
58 GOROBETS, Kostiantyn. The international Rule of Law and the idea of normative authority. Hague Journal on the Rule of Law, v. 12, 2020. p. 231.
} 
government of laws and not of men ${ }^{59}$. These are the elements that must be considered in order to understand the concept and its use as a requirement for governmental legitimacy and as a concept to be promoted in the international sphere.

Specifically with regard to the use of the concept in the international sphere, it is important to emphasize that theoretical constructions in general seek to link to the concept of the Rule of Law in the international arena to one of the substantial or formal perspectives, seeking to identify in the international sphere the presence of elements of the domestic Rule of $\mathrm{Law}^{60}$. It is for this reason that issues relating to the inclusion of formal or material elements in the definition of the Rule of Law to date permeate the doctrine on the subject in the existing debates between internationalists and legal scholars.

Beaulac $^{61}$, for example, promotes an entire reflection on the subject and concludes for the need to externalize the concept to the international sphere. Adopting Dicey's formal conception, the author, despite identifying the existence of differences between the concepts of the Rule of Law at the domestic and international levels, these differences relating to the sources of law, the subjects and the possibility of imposition and coercion (considering that there is no formal authority that creates law in the international sphere, that the States, not individuals, are the main actors and subjects and that there are no mechanisms of coercion, such as a police force, in the international sphere), concludes that "[...] the formal core values of the Rule of Law are indeed reflected, to a large extent, in the essential features of the international legal system".

However, some caution must be taken in promoting an uncritical transposition of definitions built in the domestic arena to the international sphere. There are

59 TAMANAHA, Brian Z. On the Rule of Law: history, politics, theory. Cambridge: Cambridge University Press, 2004.

60 BEAULAC, Stéphane. The Rule of Law in International Law today. In: PALOMBELLA, Gianluigi; WALKER, Neil. (ed.). Relocating the Rule of Law. Oxford: Hart Publishing, 2007. p. 197-223; MCCORQUODALE, Robert. Defining the international Rule of Law: defying gravity? International Comparative Law Quarterly, v. 65, p. 277-304, 2016; NARDIN, Terry. Theorizing the international Rule of Law. Review of International Studies, v. 34, p. 385-401, 2008; PAVEL, Carmen. The international Rule of Law. Critical Review of International Social and Political Philosophy, v. 22, p. 1-20, 2019.

${ }^{61}$ BEAULAC, Stéphane. The Rule of Law in International Law today. In: PALOMBELLA, Gianluigi; WALKER, Neil. (ed.). Relocating the Rule of Law. Oxford: Hart Publishing, 2007. p. 220. a number of particularities in the international sphere that differentiate it from the domestic sphere, so that the consideration of some elements that characterize the Rule of Law at the domestic level to define the concept in the international sphere fails to consider its own characteristics.

As explained by Nasser and Ghirardi, the "standards and certainties of domestic law are too dissimilar from those of public international law" ${ }^{2}$, mainly due to the fact that the latter one, even when seen as primarily a structured system of norms, has no central authority charged with the creation of law and its application. Unlike the internal order, organized hierarchically and vertically, the international legal order is organized horizontally and in a decentralized way, being built for the coordination of State relations. States assume voluntary commitments, there beings no central authority that can coercively enforce the law. On the contrary, at the domestic level, norms are hierarchically imposed, and compulsory compliance may be demanded, even in the face of the existence of internal officials and institutions capable of compelling individuals to observe legal norms.

Furthermore, as envisaged by Barbosa and Moschen $^{63}$, because law in the international sphere "can only be justified on the basis of a pluralist theory, its criteria for verifying validity, effectiveness and legitimacy cannot be based on the measurement criteria of national legal systems" ${ }^{\prime \prime}$. It is on this basis that it is stated that efforts to prove that international law is similar to domestic positive law and to assess the presence of elements of the domestic Rule of Law in the international level are misguided. They refer to attempts to instill a positivist perspective to international law, ignoring that it, given its particularities, is mandatory and demands compliance for other reasons, although there is no possibility of coercing States to compliance.

${ }_{62}$ NASSER, Salem Hikmat; GHIRARDI, José Garcez. Around the pyramid: Political-theoretical challenges to law in the age of global governance. Revista de Direito Internacional, Brasília, v. 15, n. 1, p. 66, 2018.

63 BARBOSA, Luiza Nogueira; MOSCHEN, Valesca Raizer Borges. O direito transnacional ("global law") e a crise de paradigma do estado-centrismo: é possível conceber uma ordem jurídica transnacional? Revista de Direito Internacional, Brasília, v. 13, n. 3, p. 154, 2016. ${ }^{64}$ In the original: "[...] somente ser passível de ser justificada a partir de uma teoria pluralista, seus critérios de averiguação de validade, eficácia e legitimidade não podem estar fundamentados com base nos critérios de aferição dos sistemas jurídicos nacionais". 
In the same sense are the considerations of Chesterman, Crawford, Gorobets and Hurd, who consider it impossible to strictly identify, in the international sphere, elements that characterize the Rule of Law at the level domestic.

Chesterman warns that the transposition of the term to the international sphere fails to consider the structural differences between international and domestic law, especially the horizontal organization of sovereign entities, as opposed to the vertical hierarchy of subjects under a sovereign, and the historical and political context within which the concept of Rule of Law is developed ${ }^{65}$. In the same sense, Crawford recalls that the application of basic domestic values of the Rule of Law to the international sphere is conditioned to an understanding of their differences, such as the fact that there is no legislative system and the fact that decisions are taken by consensus in the latter sphere ${ }^{66}$.

As Gorobets teaches, the "thin" and "thick" theories of the concept are actually the product of domestic experience and legal practices. For him, scholars forget that domestic and international versions of the Rule of Law were shaped in response to different challenges. The relevance of the term in the domestic scenario was the product of " $[\ldots]$ civil wars, revolutions, bills of rights, and oppositions to the powers of kings, princes, and nobles", while in the international space it is a product of the need to take measures destined to "[...] preventing and reducing suffering in wars, guaranteeing the autonomy of states, securing their coexistence and cooperation, achieving solidarity and furthering common goals, but also of fighting for sovereign equality and liberation". In addition, they forget that the application of the term differs in each state, arising from particular historical and constitutional developments, as well as the dominant culture in each State ${ }^{67}$.

In the same sense, Watts exposes that:

$[\ldots]$ for at least two reasons these national notions of the Rule of Law cannot be directly transposed to the international level. First, the purposes which the Rule of Law serves at the national level - usually involving the protection of the rights of the individual as

\footnotetext{
${ }^{65}$ CHESTERMAN, Simon. An International Rule of Law? American Journal of Comparative Law, v. 56, n. 2, p. 1-39, 2008.

${ }^{66}$ CRAWFORD, Jeremy. International law and the Rule of Law. Adel Law Review, v. 24, p. 3-12, 2003.

${ }^{67}$ GOROBETS, Kostiantyn. The international Rule of Law and the idea of normative authority. Hague Journal on the Rule of Law, v. 12, p. 233,2020
}

against an otherwise all-powerful governing authority - are quite different from those which it might be called upon to serve internationally; and second, the more specific requirements of the Rule of Law often reflect a State's particular historical and constitutional evolution, and differ from State to State. The international Rule of Law cannot be identified with any one national meaning of the concept ${ }^{68}$.

Therefore, the structure and history that led to the defense of the term at the international level differ significantly, removing the possibility of justifying the transposition of the term to the international level. Furthermore, as Chesterman ${ }^{69}$ and Hurd ${ }^{70}$ claim, international law in principle is not capable of satisfying some criteria used to define the term in the domestic sphere ${ }^{71}$, a fact that ends up generating the perception by the majority of researchers that there is no international concept of the Rule of Law or, at least, that the concept is deficient at the international level, being just an aspiration.

Given these considerations, what is the international conception of the Rule of Law? Is it really possible to speak of the Rule of Law in the international sphere, considering the impossibility of transposing the term in its domestic sense to the global level? If so, what are its constituent elements and how can it be promoted? These are the issues that will be discussed in the following topic.

\section{Requirements of the Rule of Law: the obligation/authority of law and the constant practices of legality}

The main objective of the Rule of Law is to limit arbitrariness in the execution of power, a concern that

${ }_{68}$ WATTS, Arthur. The international Rule of Law. German Yearbook of International Law, v. 36, p. 16, 1993.

69 CHESTERMAN, Simon. An International Rule of Law? American Journal of Comparative Law, v. 56, n. 2, p. 1-39, 2008.

${ }^{70}$ HURD, Ian. The international Rule of Law and the domestic analogy. Global Constitutionalism, v. 4, n. 3, p. 365-395, 2015.

71 As Tamanaha (2004) points out, law at the global level has unique characteristics that limit the simple analogy to the domestic definition of rule of law. This is because the international system regulates relations between States, there is no formal Legislative or Executive Power, the legal regimes applicable to a certain sovereign State are usually only those that the State chooses to accept as applicable, courts operate based on consensus, and there is no institutionalized apparatus capable of coercively imposing sanctions. Under these conditions, the notion of the rule of law at the international level is elusive, depending on other criteria for its characterization. In: TAMANAHA, Brian Z. On the Rule of Law: history, politics, theory. Cambridge: Cambridge University Press, 2004. 
is valid both in international law and in domestic legal systems. In this sense, Sundfeld ${ }^{72}$ explains that, in general terms, the Rule of Law "is what is subordinated to the Law, that is, subject to legal norms regulating its action" 73 (free translation), in contrast to the Police State, where only individuals were subject to the law and power was exercised without legal limitations.

The nature of such concern with the necessity of limiting arbitrariness varies across different societies, cultures and policies, but the fact is that the need to limit State authorities' power has always been constant among societies. According to Tamanaha, one of the great contributions of the Rule of Law is precisely to provide an answer to this need ${ }^{74}$.

The internationalization of the concept of Rule of Law, in this sense, has significance, considering that it reaffirms the possibility of international law serving as an important element to contain abuse of power and arbitrariness. Its applicability in the international sphere is supported by a variety of international organizations that attempt to conceive it as an ideology for international law, however, even so, the role of the Rule of Law is assumed, and the real meaning of the concept in the international sphere, the practical differences between the application of the term domestically and globally and the reasons for its promotion remain unclear ${ }^{75}$.

Despite the constant reference to the Rule of Law at the international level in statements by the General Assembly, the Secretary General and the UN Security Council, these statements, in fact, only concern how the Rule of Law must operate in national systems, repeating the concept used to define the term in some domestic systems. At no point there is an attempt to explain which elements of the term are applicable to the international sphere, how it can be conceptualized, how it differs from the Rule of Law in the domestic sphere and how it can be promoted ${ }^{76}$.

\footnotetext{
72 SUNDFELD, Carlos Ari. Fundamentos de Direito Público. 5. ed. São Paulo: Malheiros, 2012. p. 37.

${ }^{73}$ In the original: "[... é o que se subordina ao Direito, vale dizer, que se sujeita a normas jurídicas reguladoras de sua ação".

${ }^{74}$ TAMANAHA, Brian Z. On the Rule of Law: history, politics, theory. Cambridge: Cambridge University Press, 2004.

${ }^{75}$ GOROBETS, Kostiantyn. The international Rule of Law and the idea of normative authority. Hague Journal on the Rule of Law, v. 12, p. 227-249, 2020.

${ }^{76}$ MCCORQUODALE, Robert. Defining the international Rule of Law: defying gravity? International Comparative Law Quarterly, v. 65, p. 277-304, 2016.
}

Given these considerations and based on the perspective that the Rule of Law is applicable to international relations, even if in different ways than the Rule of Law at the domestic level, it is understood that the affirmation of the existence of an international conception of the Rule of Law does not depend on the merely formal analysis of the law. Nor does it depend on analyzing the presence of substantial elements. It is considered that this statement, in reality, depends on the evaluation of the presence of a specific element, namely, the perception of the obligation or authority of international law.

In this line of interpretation, researchers such as Brunnée and Toope ${ }^{77}$ and Gorobets ${ }^{78}$, sought to demonstrate in what sense it is possible to speak of the Rule of Law without this transposition of the term from the domestic to the external sphere. Although they start from different theoretical basis, Brunnée and Toope presenting a constructivist analysis of law and Gorobets presenting an intermediate analysis between constructivism and Matias Kumm's ${ }^{79}$ positivism, they commonly emphasize that only in scenarios where the existence of a basic element is identified, that is, the authority (for Gorobets) or obligatory nature (for Brunnée and Toope) of international law, it is possible to affirm the existence of Rule of Law in the international sphere. In this context of discussions, an urgent measure for the promotion of the Rule of Law at the international level would be to increase the recognition of international law's obligatory nature or authority.

Although the obligation or authority of law, called legitimacy by Thomas Franck ${ }^{80}$, is also a relevant aspect

77 BRUNNÉE, Jutta; TOOPE, Stephen. Legitimacy and legality in international law: an interactional account. Cambridge: Cambridge University Press, 2010.

78 GOROBETS, Kostiantyn. The international Rule of Law and the idea of normative authority. Hague Journal on the Rule of Law, v. 12, p. 227-249, 2020.

${ }_{79}$ Kumm also refers to the authority of law as an essential element for affirming the existence of a legitimate international Rule of Law. His analysis, although important, is of a positivist nature, the scholar arguing that the relationship between authority and law arises solely from the legitimacy of the law, gained from the mere existence of four principles: international legality; subsidiarity; adequate participation and accountability; and achieving results that do not violate fundamental rights and are reasonable. In: KUMM, Mattias. International law in national courts: the international Rule of Law and the limits of the internationalist model. Virginia Journal of International Law, v. 44, p. 22, 2003.

${ }^{80}$ FRANCK, Thomas M. The Power of Legitimacy among Nations. New York: Oxford University Press, 1990. 
for the Rule of Law in the domestic sphere, the factors that are essential for its perception in the international sphere are distinct from the factors that promote it internally.

As already mentioned, the distinctive features of international law, characterized by its horizontality, decentralization, voluntariness and the absence of a central authority that can enforce the law, does not remove the obligation to comply with international standards, but only implies the need to consider that this obligation is derived from other elements, different from those that impose it internally.

In the domestic sphere, Gorobets teaches that such authority results from the presence of elements of the Rule of Law (whatever the concept adopted) and the existence of a "mediation of authority", that is, the existence of officers who are functionally and institutionally differentiated from the subjects of rights and are responsible for the creation, interpretation and application of the law. That is, the authority of domestic law stems from the existence of valid laws applicable to all, the existence of institutions and officials that can apply the law and the acceptance, by the people, of the legitimacy that authorities and officials have for the exercise of the abovementioned functions ${ }^{81}$.

On the other hand, in the international sphere, because there is no such mediation, due to the horizontal nature of the creation and modification of international law, authority would not derive from institutions and officials, an aspect that, even so, would not imply the perception that there is no Rule of Law at the international level ${ }^{82}$.

In addition to the perspective of Gorobets, Brunnée and Toope elucidate that in order to make possible this affirmation of the obligatory nature of international law and the effective affirmation of the existence of a Rule of Law in the international sphere, it is not necessary to consolidate this "mediation of authority", but to create conditions so that international law is perceived by the subjects to which it is directed as endowed with authority and, therefore, as mandatory ${ }^{83}$.

${ }^{81}$ GOROBETS, Kostiantyn. The international Rule of Law and the idea of normative authority. Hague Journal on the Rule of Law, v. 12, p. 227-249, 2020.

82 GOROBETS, Kostiantyn. The international Rule of Law and the idea of normative authority. Hague Journal on the Rule of Law, v. 12, p. 227-249, 2020.

83 BRUNNÉE, Jutta; TOOPE, Stephen. Legitimacy and legality in in-
To this extent, it is required that the law be endowed with a quality that is different from the other (non-legal) rules of conduct, which generate consequences on the behavior, conduct and practices of State authorities. Only in this case would it be possible to speak of an international conception of the Rule of Law. With this in mind, what would be the factors that could generate this perception, considering that there is no international "mediation of authority"? How is it possible to elevate this perception and, thus, progressively create conditions for the effective consolidation of the Rule of Law in the international sphere?

To answer such questions, the research constructed by Gorobets is significant. At first, the researcher reaffirms the essentiality of an international conception of the Rule of Law and the search for its promotion, arguing that its significance stems from the fact that it provides a normative framework to be used to justify or question social practices. Given this, the academic asserts that the Rule of Law at the international level refers to a meta-normative ideal that reflects the merits of a legal order, in the sense that it allows its subjects to guide their actions and adapt their behavior according to predefined parameters ${ }^{84}$. Such construction enables the understanding of the value that the Rule of Law has to direct the actions of the individuals and States it is addressed to.

The scholar emphasizes that this merit, however, derives not only from formal elements of international law, but also from the authority of $1 \mathrm{lw}^{85}$, which in his perspective derives from an intrinsic quality of the norms ${ }^{86}$ combined with the perpetuation of repeated

ternational law: an interactional account. Cambridge: Cambridge University Press, 2010.

${ }^{84}$ GOROBETS, Kostiantyn. The international Rule of Law and the idea of normative authority. Hague Journal on the Rule of Law, v. 12, p. 227-249, 2020.

85 Authority, teaches Gorobets, refers to a special relationship that is established between the law and its addressees. A significant issue is that it affects the practical reasoning of its subjects, in the sense of highlighting the subjects' obligation to observe the rules. In: GOROBETS, Kostiantyn. The international Rule of Law and the idea of normative authority. Hague Journal on the Rule of Law, v. 12, p. 227-249, 2020.

${ }^{86}$ Regarding this intrinsic quality, Gorobets explains that it is derived both from the fact that States limit themselves through international law, authority being recognized through their own subjection to a set of standards of conduct that represent a balance of reasons that are applied to them. In: GOROBETS, Kostiantyn. The international Rule of Law and the idea of normative authority. Hague Journal on the Rule of Law, v. 12, p. 227-249, 2020. 
practices that meet conditions of legality, not deriving, therefore, from an institutional structure external to the law (as opposed, therefore, to the authority that exists in domestic orders). ${ }^{87}$ Therefore, the Rule of Law at the international level, for the author, would come from this quality and from repeated practices, as it provides subjects with protected reasons that legitimize actions in the search for ensuring compliance and avoiding abuses.

Gorobets asserts that the Rule of Law is what enables the perception that the reasons offered by law are protected reasons, the concept in this sense constituting an element that lies between the mere affirmation of the normative authority of law and the effective assertion of such authority by the subjects of $\operatorname{law}^{88}$. Thus, the progressive construction of this perception of authority, through repeated legal practices, would allow the affirmation of the existence of an international conception of the Rule of Law. In the same sense, Nasser and Ghirardi assert that Law in the international order is, in effect, the result of negotiations and accumulated practice, combined with the conviction that such practice is legally binding ${ }^{89}$.

Such construction resonates with the ideas presented by Fuller in his legal theory ${ }^{90}$, especially in light of such scholar's finding that the law, based on criteria of legality, allows men to organize their lives and their relationships with one another (giving them protected reasons) and to limit the potential abuse of authority, just as practical rationing with norms enables the building of fidelity to the norms of the legal system. In the same sense, Gorobets teaches that the Rule of Law is important for guiding actions, as it gives agents reasons for action ${ }^{91}$.

\footnotetext{
${ }^{87}$ Gorobets points out that authority in the domestic sphere is distinct, not arising only from an intrinsic quality of norms, but from the acceptance of the authority of officials who create, interpret and apply the law. Delegation of authority at the domestic level assumes that the end result of institutional deliberations must be accepted. In: GOROBETS, Kostiantyn. The international Rule of Law and the idea of normative authority. Hague Journal on the Rule of Law, v. 12, p. 227-249, 2020.

${ }^{88}$ GOROBETS, Kostiantyn. The international Rule of Law and the idea of normative authority. Hague Journal on the Rule of Law, v. 12, p. 227-249, 2020.

89 NASSER, Salem Hikmat; GHIRARDI, José Garcez. Around the pyramid: Political-theoretical challenges to law in the age of global governance. Revista de Direito Internacional, Brasília, v. 15, n. 1, p. 61 69, 2018.

${ }^{9}$ FULLER, Lon. The morality of law. New Haven: Yale University Press, 1969.

${ }^{91}$ GOROBETS, Kostiantyn. The international Rule of Law and the
}

It is understood that in any legal system (whether domestic or international) the existence of formal elements characteristic of the Rule of Law (legality, supremacy of law, equality before the law and application of law by courts, according to Dicey) induces the perception of authority or obligation. The norms, being formally consolidated, attract their own adherence, as they appear to be legitimate in the eyes of those to whom they are addressed. This is because the identification of the law as arising from transparent, clear and pre-fixed processes, as originated from authorities that hold power to create the law, as being non-discriminatory and as being possibly imposed on violators, in principle, consolidates the idea that it must be obeyed.

However, especially in the international system, precisely because of its coercive deficiency, it is required, in addition to aspects of formality, the continuous construction of an international social system in which norms are seen as appropriate and mandatory, a construction that only occurs through repeated practices based on international law. The form of law alone is not enough to generate changes in behavior. Such perception is due to the consideration that the social system has an eminent impact on State and other international actors' conduct and, consequently, on the degree of compliance with international norms and on the perception of the authority of the law.

This position is also in line with the teachings of Konrad Hesse. The renowned scholar, despite making analyzes that are restricted to the domestic constitutional legal order, seeking to delimit the factors that give normative force to the Constitution, makes important contributions to the understanding of the elements that give force to law as a whole, including international law. In seeking to outline how power is not an unrestricted element, being limited by law, and how norms cannot be simply disregarded, the theorist essentially explains that the normative force of legal commandments depends, in reality, on the content of the commandment and, specifically, of legal praxis, that is, of constant practices and concrete action. In this view, the meaning of legal order in reality can only be appreciated if such order and reality are considered in their dialogical relationship,

idea of normative authority. Hague Journal on the Rule of Law, v. 12, p. 227-249, 2020. 
in their inseparable context and their reciprocal conditioning ${ }^{92}$.

In this sense, the idea of the need to strengthen existing coercive mechanisms in the international system for the consolidation of the Rule of Law at the international level is refuted. As such, legality, equality before the law, the supremacy of law and the presence of a coercive apparatus in the international sphere are important (and essential, indeed), but the presence of such elements is of no use if interactions between agents and structures are not possible and there is no effective articulation with the international system through constant practices of legality. Such practices are the ones that constantly build and rebuild the Rule of Law at the international level.

In alignment with this view, Teixeira and Köche explain that the traditional conceptions, marked by the figure of the State, by power, by normativity and by structural criteria do not explain the judicial phenomenon in global terms, which is more complex and brand, demanding, for the perception of its authority, that dynamic interactions and practices in the global arena be constantly conduced ${ }^{93}$.

This is also the understanding of Brunnée and Toope, who, using the considerations of Fuller ${ }^{94}$, build an "interactional theory of law" (consisting of a "theory of legal obligation"), to demonstrate how the Rule of Law is constantly shaped through "practices of legality" and, at the same time, how the formal legality of law and the other elements of the Rule of Law shape interactions between agents and structures, creating the perception of the mandatory nature of international norms ${ }^{95}$. This idea is allied with Fuller's conception that

\footnotetext{
92 HESSE, Konrad. A força normativa da Constituição. Tradução: Gilmar Ferreira Mendes. Porto Alegre: Sergio Antonio Fabris, 1991.

93 TEIXEIRA, Anderson Vichinkeski; KÖCHE, Rafael. Um direito sem estado? Direitos humanos e a formação de um novo quadro normativo global. Revista de Direito Internacional, Brasília, v. 10, n. 2, p. 86-100, 2013.

94 A difference with regard to Fuller's doctrine is that Brunnée and Toope focus their analysis on the international system and, in addition, seek to draw a difference between legal norms and other forms of social normativity, a difference that was never Fuller's focus. For the professors, some distinction between legal obligations and broader social norms is crucial to sustaining the rule of law tradition that characterizes the international system.

95 BRUNNÉE, Jutta; TOOPE, Stephen. Interactional legal theory, the international Rule of Law and global constitutionalism. In: LANG, A.; WIENER, A. (ed.). Handbook on global constitutionalism. Cheltenham: Edward Elgar Publishing, 2017. p. 170-182.
}

law does not refer to a finished project, but to a constant challenge, which is formed and maintained through continuous social practices, so that, for its existence and consolidation it depends on the effective interaction and cooperation between agents and structures ${ }^{96}{ }^{97}$.

For Brunnée and Toope, what distinguishes law from other types of social ordinances is the adherence to specific legality requirements, associated with the Rule of Law. Such adherence, for the researchers, is not achieved by power or force (which in their view does not explain the sense of obligation that must exist in international law), or simply due to the existence of formal elements of law, but in view of the existence of a sense of obligation (which constitutes the additional value of law) that only arises when States and other actors perceive the process of creating the law as legitimate and they interact with international norms, through constant practices of legality ${ }^{98}$. In this view, it is the continuous interactions between different actors and international structures that promote and enable the affirmation of the existence of an international concept of the Rule of Law, considering that they create a social environment in which the obligation of respect for international standards ${ }^{99}$.

In the discussion about Rule of Law in the international sphere, what is noted is that scholars of law and international relations see the obligation as a mere legal consequence of formal validity or state consent ${ }^{100}$, while others, in the opposite perspective, do not inqui-

96 FULLER, Lon. The morality of law. New Haven: Yale University Press, 1969.

${ }^{97}$ Fuller, despite referring eminently to the domestic legal system when elaborating his legal theory, believed in the mutuality between agents and structures, arguing that the understanding of law requires that attention be paid to both the actors and the structures in which such actors interact. The relevance of his contributions, moreover, stems from the fact that the legal scholar manages to explain the law by admitting and maintaining diversity, an aspect that is relevant when one understands that society is eminently polycentric and culturally diverse, a fact that implies the impossibility of defending a single political morality or the existence of a single central political authority. In: FULLER, Lon. The morality of law. New Haven: Yale University Press, 1969.

98 BRUNNÉE, Jutta; TOOPE, Stephen. Interactional legal theory, the international Rule of Law and global constitutionalism. In: LANG, A.; WIENER, A. (ed.). Handbook on global constitutionalism. Cheltenham: Edward Elgar Publishing, 2017. p. 170-182.

99 BRUNNÉE, Jutta; TOOPE, Stephen. Legitimacy and legality in international law: an interactional account. Cambridge: Cambridge University Press, 2010.

100 HENKIN, Louis. How nations behave: law and foreign policy. New York: Columbia University Press, 1979. 
re about this issue of obligation, since they understand that it does not exist, international actors acting in accordance with interests and rational choices ${ }^{101}$.

Brunnée and Toope, based on the theories of important constructivist academics such as Thomas Franck, Abraham Chaynes and Antonia Handler Chaynes, Ryan Goodman and Derek Jinks, and Harold Koh, emphasize, however, that inquiry concerning this obligation is necessary, precisely because it is from this obligation that the constant reinforcement and reconstruction of the Rule of Law at the international level is promoted. The scholars illustrate why the analysis of the Rule of Law in the international sphere should pay more attention to the issue of obligation, the relevance of their considerations arising from the fact that they refer both to the properties of norms (as they influence and shape behavior) and to the importance of the legal process for consolidating the Rule of $\mathrm{Law}^{102}$.

The theorists clarify, at first, that the obligation (in the same sense as the authority of Gorobets) is relevant not because it is something externally imposed on actors, but because it is something that results from the commitment of all actors to a legal system and its nor$\mathrm{ms}$, which generates an attitude in favor of the law that is part of the actors' very identity. In a second moment, they teach that such an obligation cannot be understood solely in terms of formal validity, because the formal characteristics of norms, by themselves, do not clarify how they generate influence. For them, the Rule of Law exists when the rules that meet the criteria of legality are embedded in real practices ${ }^{103}$.

As to such consideration, that is, that not only formality but also practices of legality generate obligations, the professors, referring to the legitimacy criteria of Thomas Franck ${ }^{104}{ }^{105}$, express that:

101 DOWNS, George W.; JONES, Michael A. Reputation, compliance, and international law. The Journal of Legal Studies, v. 31, p. 95114, 2002; WALTZ, Kenneth N. Theory of International Politics. New York: McGraw-Hill, 1979.

102 BRUNNÉE, Jutta; TOOPE, Stephen. Legitimacy and legality in international law: an interactional account. Cambridge: Cambridge University Press, 2010.

103 BRUNNÉE, Jutta; TOOPE, Stephen. Legitimacy and legality in international law: an interactional account. Cambridge: Cambridge University Press, 2010.

104 FRANCK, Thomas M. The Power of Legitimacy among Nations. New York: Oxford University Press, 1990.

105 While Franck understands that legitimacy is a trait that can be added to norms that are already mandatory, Brunnée and Toope, on the other hand, understand that obligation does not stem only
The legitimacy of legal rules is enhanced when they substantially meet criteria such as generality, promulgation, reasonableness, clarity or predictability criteria that overlap with Franck's legitimacy factors. As we have explained, fulfilment of these requirements builds legal legitimacy because these features enable actors to reason with law. But interactional obligation must also be practiced to maintain its influence ${ }^{106}$.

Legality, in this view, is relevant to creating a sense of obligation. However, interactions, constant legal practices, are of paramount importance for the effective consolidation of the Rule of Law at the international level. The defense of these repeated practices as an essential element is based on Aristotle's "practical reasoning", implying the consideration that the Rule of Law in the international sphere is best understood as a discursive exercise, as a form of rhetoric that is carried out with a purpose, so that it is modified and reinforced through continuous practices of contestation, interpretation and application, which is consolidated through constant interactions ${ }^{107}$.

Furthermore, Tamanaha also points out the importance of rhetoric for the Rule of Law, clarifying that, over time, rhetoric becomes a dominant cultural value and a vision of government and law shared by almost everyone $^{108}$. The assertion that the government is limited by law and the belief in this idea over time becomes a reality, depending on constant reassurance, through constant practices.

Regarding this consideration, Brunnée and Toope articulate that the process of creating legal obligation is composed of three phases: a) first, States and actors build common interests about what they want to achieve through the law; b) second, international actors must ensure that legality criteria are observed; c) third, the norms in question must be constantly reinforced through an ongoing practice of legality. In view of this third phase, what is observed is that the mandatory power of

from the mere legitimacy of the rules, the authors adding the need of the continuous participation of relevant actors in the process of building the law and of constant practices based on legality criteria. 106 BRUNNÉE, Jutta; TOOPE, Stephen. Legitimacy and legality in international law: an interactional account. Cambridge: Cambridge University Press, 2010. p. 96.

107 BRUNNÉE, Jutta; TOOPE, Stephen. Interactional legal theory, the international Rule of Law and global constitutionalism. In: LANG, A.; WIENER, A. (ed.). Handbook on global constitutionalism. Cheltenham: Edward Elgar Publishing, 2017. p. 170-182.

108 TAMANAHA, Brian Z. On the Rule of Law: history, politics, theory. Cambridge: Cambridge University Press, 2004. 
law, intrinsic to the concept of the Rule of Law, must be cultivated and maintained, through a legal process of constant interaction ${ }^{109}$.

This interactional legal process reaffirms and rebuilds the Rule of Law, the consolidation of the Rule of Law at the international level being, thus, a constant effort. This is because it is from such interactional practice that it is revealed when power is exercised arbitrarily and without legitimacy (violating the Rule of Law). In this sense, the Rule of Law, despite having a connotation of stability (generating predictability and legal certainty), must be seen internationally as a dynamic concept that is dependent on a continuous process of reinforcement, precisely because the constant interactions between processes and mechanisms, or better, practices of legality, generate a sense of obligation of international law ${ }^{110}$.

When there is a practice of legality, actors can pursue their interests and organize interactions through the law $^{111}$. The Rule of Law in the international sphere is the product of "[...] a felt sense of obligation, rooted in a specific form of legal legitimacy"112, which arises not only from the formal structure of norms, but of the legal process, of constant interactions based on law.

In the domestic sphere, what is defended when talking about the Rule of Law is the need to guarantee of access to a non-discriminatory justice and to build institutions and strengthen accountability mechanisms, which are capable of holding authorities accountable in case of arbitrariness or abuse of power. At the international level, on the other hand, although such elements are important, it is the interaction between agents and structures that promotes the Rule of Law, precisely because it is through these interactions, through legal

\footnotetext{
109 BRUNNÉE, Jutta; TOOPE, Stephen. Interactional legal theory, the international Rule of Law and global constitutionalism. In: LANG, A.; WIENER, A. (ed.). Handbook on global constitutionalism. Cheltenham: Edward Elgar Publishing, 2017. p. 170-182.

110 BRUNNÉE, Jutta; TOOPE, Stephen. Interactional legal theory, the international Rule of Law and global constitutionalism. In: LANG, A.; WIENER, A. (ed.). Handbook on global constitutionalism. Cheltenham: Edward Elgar Publishing, 2017. p. 170-182.

111 BRUNNÉE, Jutta; TOOPE, Stephen. Interactional legal theory, the international Rule of Law and global constitutionalism. In: LANG, A.; WIENER, A. (ed.). Handbook on global constitutionalism. Cheltenham: Edward Elgar Publishing, 2017. p. 170-182.

112 BRUNNÉE, Jutta; TOOPE, Stephen. Legitimacy and legality in international law: an interactional account. Cambridge: Cambridge University Press, 2010. p. 124.
}

practices, that conditions are built for the elevation of the perception of international law's obligatory nature.

\section{Conclusion}

The issue relating to the need to promote the Rule of Law is perceived by the international community as a pressing challenge and as one of imperative analysis. This is because it is through such promotion that conditions are created for advancing in the protection of human rights and in the consolidation of democracy and sustainable development.

However, when the promotion of the Rule of Law at the international level is discussed, a series of controversies permeate the theme, especially in light of the fact that there is not only one definitive concept of Rule of Law. The concept is influenced and derived from cultural and historical aspects, so that the definition given to the term depends on the analysis of the social and political context in which the construction is formulated. In view of this, the impossibility of speaking of the Rule of Law at the international level as something beyond a political ideal to be pursued is often asserted.

Attempts to uncritically transpose elements that serve to characterize the Rule of Law within liberal states to the international legal order lead to problems, given the differences between international law and domestic law, such as the fact that there is no an effective separation of powers or a mediation of authority at the international level. For this reason, despite the repeated affirmation by the international community of the essentiality of promoting the Rule of Law at the international level, during this work it was found that it is difficult to accurately delineate the elements that influence the promotion of the Rule of Law in the international sphere.

Despite the difficulties, however, after considering the elements that are inherently part of the concept and analyzing the different formal and substantial perspectives that are usually used to characterize the term, the need to partake a differentiated view when dealing with the promotion of the Rule of Law in the international order was perceived, precisely because of its coercive deficiency, when compared to domestic law. 
Following the theoretical constructions of Brunnée and Toope and Gorobets, it was outlined that this differentiate perspective is strictly related to the understanding that an international conception of the Rule of Law is eminently linked not only to the existence and identification of formal elements of law in the international sphere (that is, the identification of the presence of aspects of legality, equality before the law, supremacy of law and application of law by courts of law), but also, and of greater importance, the existence of a repeated articulation of different actors with the international legal system, through constant practices of legality. It is through these practices that the perception of the mandatory nature of international law is raised, an element that was found to be intrinsic to the concept of the Rule of Law.

Such perspective derives from the perception that Law considered in itself never refers to a finished project. The Rule of Law refers to a constant challenge, which is formed and maintained by continuous practices, depending in this way on the effective interaction and cooperation between agents and structures. In this sense, it was assessed that the promotion of the Rule of Law in the international sphere is not necessarily only about the strengthening of coercive mechanisms in the international sphere (although the doctrine in general urgently defends this need for such strengthening), but mainly of building a social environment in which the obligation/authority of international law is recognized, a construction that is carried out by constant practices of legality.

\section{References}

ARAJÄRVI, Noora. The Rule of Law in the 2030 Agenda. The Hague Journal on the Rule of Law, Berlin, v. 10, n. 1, p. 187-217, 2018.

BARBOSA, Luiza Nogueira; MOSCHEN, Valesca Raizer Borges. O direito transnacional ("global law") e a crise de paradigma do estado-centrismo: é possível conceber uma ordem jurídica transnacional? Revista de Direito Internacional, Brasília, v. 13, n. 3, p. 145-158, 2016.

BEAULAC, Stéphane. The Rule of Law in International Law today. In: PALOMBELLA, Gianluigi; WALKER, Neil. (eds.). Relocating the Rule of Law. Oxford: Hart Publishing, 2007. p. 197-223.
BINGHAM, Tom. The Rule of Law. Londres: Penguin Books, 2010.

BOBBIO, Norberto. Liberalism and Democracy. Translation: Martin Ryle and Kate Soper. London: Verso, 1990.

BRUNNÉE, Jutta; TOOPE, Stephen. Interactional legal theory, the international Rule of Law and global constitutionalism. In: LANG, A.; WIENER, A. (eds.). Handbook on global constitutionalism. Cheltenham: Edward Elgar Publishing, 2017. p. 170-182.

BRUNNÉE, Jutta; TOOPE, Stephen. Legitimacy and legality in international law: an interactional account. Cambridge: Cambridge University Press, 2010.

CHESTERMAN, Simon. An International Rule of Law? American Journal of Comparative Law, v. 56, n. 2, p. 1-39, 2008.

CRAWFORD, Jeremy. International law and the Rule of Law. Adel Law Review, v. 24, p. 3-12, 2003.

DICEY, Albert Venn. Introduction to the Study of the Law of the Constitution. London: Macmillan and Co, 1915.

DOWNS, George W.; JONES, Michael A. Reputation, compliance, and international law. The Journal of Legal Studies, v. 31, p. 95-114, 2002.

DWORKIN, Ronald. A matter of principle. Cambridge: Harvard University Press, 1985.

ETHERTON, Terence. The universality of the Rule of Law as an international standard. Israel Law Review, v. 53, n. 3, p. 469-483, 2018.

FRANCK, Thomas M. The Power of Legitimacy among Nations. New York: Oxford University Press, 1990.

FULLER, Lon. The morality of law. New Haven: Yale University Press, 1969.

GOROBETS, Kostiantyn. The international Rule of Law and the idea of normative authority. Hague Journal on the Rule of Law, v. 12, p. 227-249, 2020.

HAYEK, Friedrich August von. Law, Legislation and Liberty: rules and order. Chicago: University of Chicago Press, 1978.

HENKIN, Louis. How nations bebave: law and foreign policy. New York: Columbia University Press, 1979.

HESSE, Konrad. A força normativa da Constituição. Tradução: Gilmar Ferreira Mendes. Porto Alegre: Sergio Antonio Fabris, 1991. 
HURD, Ian. The international Rule of Law and the domestic analogy. Global Constitutionalism, v. 4, n. 3, p. 365395, 2015.

KIRCHHEIMER, Otto. The Rechtsstaat as Magic Wall. In: SCHEUERMAN, William E. (ed.) The Rule of Law under siege: selected essays of Franz L. Neumann and Otto Kirchheimer. California: University of California Press, 1996. p. 243-263.

KOSKENNIEMI, Martti. Entre a apologia e a utopia: A política do direito internacional. Revista de Direito Internacional, Brasilia, v. 15, n. 1, p. 5-29, 2018.

KOSKENNIEMI, Martti. From apology to utopia: the structure of international legal argument. Cambridge: Cambridge University Press, 2005.

KRYGIER, Martin. Rule of Law (and Rechtsstaat). In: SILKENAT, James R.; HICKEY JR., James E.; BARANBOIM, Peter D. (ed.) The Legal Doctrines of the Rule of Law and the Legal State (Rechtsstaat). Switzerland: Springer, 2014. p. 45-60.

KUMM, Mattias. International law in national courts: the international Rule of Law and the limits of the internationalist model. Virginia Journal of International Law, v. 44, p. 19-32, 2003.

MCCORQUODALE, Robert. Defining the international Rule of Law: defying gravity? International Comparative Law Quarterly, v. 65, p. 277-304, 2016.

NARDIN, Terry. Theorizing the international Rule of Law. Review of International Studies, v. 34, p. 385-401, 2008.

NASSER, Salem Hikmat; GHIRARDI, José Garcez. Around the pyramid: Political-theoretical challenges to law in the age of global governance. Revista de Direito Internacional, Brasília, v. 15, n. 1, p. 61-69, 2018.

PALOMBELLA, Gianluigi. The Rule of Law as an institutional ideal. In: MORLINO, Leonardo; PALOMBELLA, Gianluigi (ed.). Rule of Law and democracy: inquiries into internal and external issues. Leiden: Brill, 2010. p. 3-37.

PAVEL, Carmen. The international Rule of Law. Critical Review of International Social and Political Philosophy, v. 22, p. 1-20, 2019.

PEERENBOOM, Randall. Human Rights and Rule of Law: what's the relationship? Georgetown International Law Review, v. 36, p. 809-945, 2005.
RAZ, Joseph. The authority of law: essays on law and morality. 2. ed. Oxford: Oxford University Press, 2009.

RAZ, Joseph. The Rule of Law and its Virtue. In: RAZ, Joseph. The authority of Law: essays on Law and morality. Oxford: Clarendon Press, 1979.

SANTOS, Gilberto Antônio Duarte. O conceito de Rule of Law nas relaçôes internacionais: direitos humanos e restrições à liberdade de navegação nos oceanos. 2015. Dissertação (Mestrado em Relações Internacionais) Instituto de Relações Internacionais, Universidade de Brasília, Brasília, 2015.

SELLERS, Mortimor N. S. What is the Rule of Law and why is it so important? In: SILKENAT, James R.; HICKEY JR., James E.; BARANBOIM, Peter D. (ed.). The legal doctrines of the Rule of Law and the Legal State (Rechtsstaat). Switzerland: Springer, 2014. p. 3-14.

SELZNICK, Philip. Legal cultures and the Rule of Law. In: KRYGIER, Martin; CZARNOTA, Adam. (ed.) The Rule of Law after communism. Aldershot: Ashgate/Dartmouth, 1999. p. 21-38.

SUNDFELD, Carlos Ari. Fundamentos de Direito Público. 5. ed. São Paulo: Malheiros, 2012.

TAMANAHA, Brian Z. On the Rule of Law: history, politics, theory. Cambridge: Cambridge University Press, 2004.

TEIXEIRA, Anderson Vichinkeski; KÖCHE, Rafael. Um direito sem Estado? Direitos humanos e a formação de um novo quadro normativo global. Revista de Direito Internacional, Brasília, v. 10, n. 2, p. 86-100, 2013.

UNITED NATIONS [UN]. Security Council. Repport n. S/2004/616. The Rule of Law and transitional justice in conflict and post-conflict societies: report of the Secretary General. UN Security Council, 2004. Available at: https:/ / www.securitycouncilreport.org/un-documents/document/pcs-s-2004-616.php. Accessed in: 25 May 2020.

WALTZ, Kenneth N. Theory of International Politics. New York: McGraw-Hill, 1979.

WATTS, Arthur. The international Rule of Law. German Yearbook of International Law, v. 36, p. 15-45, 1993. 
Para publicar na Revista de Direito Internacional, acesse o endereço eletrônico www.rdi.uniceub.br ou www.brazilianjournal.org.

Observe as normas de publicação, para facilitar e agilizar o trabalho de edição. 